В. С. Головіна

\title{
МОВНІ ЗАСОБИ ВИРАЖЕННЯ МІСЬКОГО ПРОСТОРУ У ТВОРЧОСТІ М. СЕМЕНКА ЯК ПРЕДСТАВНИКА МОДЕРНІЗМУ
}

Головіна В. С. Мовні засоби вираження міського простору у творчості М. Семенка як представника модернізму.

У статті досліджується структура художнього простору в поезї у зв’язку з лексикосемантичними засобами вираження реалістичного простору міста і різних явищ, що визначають його. Розглядаються питання про традиції та новаторство, динаміку розвитку мовного образу світу поета.

Ключові слова: простір, мовний образ простору, простір міста.

Головина В. С. Языковые средства выражения городского пространства в творчестве М. Семенка как представителя модернизма.

В статье исследуется структура художественного пространства в поэзии в сочетании с лексикосемантическими средствами выражения реалистического пространства города и различных определяющих его явлений. Рассматриваются вопросы традиций и новаторства, динамики развития языкового образа мира поэта.

Ключевые слова: пространство, языковой образ пространства, пространство города.

Golovina V. S. The language way of expression of city space in M. Semenko's poetry

The article deals with the the structure of art space in connection with lexical and semantic ways of expression of realistic city space. The questions on traditions and innovation, dynamic of development of a language image of the world at the poet are examined.

Key words: space, language image of space, space of city. 
Розвиток теми міста в українській літературі простежується з давніх часів, але незмінним залишається те, що майже завжди місто протиставляється селу. Найбільш активно розробляти проблему міста почали у 20-х роках XX століття. Це пов'язано з активними суспільними змінами, які відбувалися в цей час - перехід від усталеного звичного сільського життя до механізованого міського, до якого люди лише почали звикати i пристосовуватися. Цей процес не залишився поза увагою тогочасних письменників, серед яких Михайль Семенко посідає належне місце. На думку Юрія Шереха, «вся література 20 -х років... була у своїй великій частині антисільською. Антисільським був Семенко в оспівуванні міста, трамваїв, кав'ярень i машин, неокласицизм у полоні міських білоколонних див і університетської мудрості; Хвильовий, закоханий у вічноплинні арабески неугавного міського руху; Яновський... Йогансен... Серед провідних постатей тогочасної літератури дуже мало було оборонців села: ... Косинка, Осьмачка. Годі зрозуміти все літературне життя двадцятих років, якщо скреслити 3 нього боротьбу цих двох течій урбаністичної й сільської» [7, с. 90]. С. Павличко в дослідженні «Дискурс модернізму в українській літературі», зазначала, що в українській літературі «перетворення сільської культури в міську ніколи остаточно не завершилося, ставлення до міста стало лакмусом позиції митця, а дискурс міста позначений глибоким і болісним конфліктом» [5, с. 65].

Традиційний міф села як носія усталених культурних стереотипів починає вичерпувати себе в умовах бурхливих соціальних перетворень. Нова, урбаністична свідомість стає необхідною, назрілою для реалізації, але водночас і неприступною для українців унаслідок політики Російської імперії, у якій міста як осередки цивілізації призначалися лише пануючій нації. Українське село було невід'ємним від російської культури. Тому селяни 20-х років, приходячи в місто, неминуче відчували конфлікт двох культурних традицій і поставали перед дилемою: піддатися нівелюючому впливу індустріальних монстрів чи зберегти недоторканою одвічну українську патріархальність, тим відкинувши себе на периферію сучасних подій і явищ. У будь-якому разі селянин був приречений завжди відчувати власну чужинність, перебувати в постійній боротьбі 3 собою й навколишнім середовищем.

Михайло (Михайль) Семенко (1892-1937) належить до тих українських письменників 20-30-х років XX століття, які своєю творчістю зробили помітний внесок у розвиток української літератури й української літературної мови. Після трагічної загибелі цих поетів їх творчий доробок протягом десятиліть не досліджувався, проте i в наші дні про їх літературну спадщину згадують хіба що до ювілейних дат та дуже стисло в історії української літератури. Більш докладна характеристика творів М. Семенка міститься тільки в деяких статтях, зокрема в тих, що передують збіркам його поезій. Зараз, коли оцінка авангардизму в 
мистецтві змінюється, творчість М. Семенка чекає більш уважного вивчення й об'єктивної оцінки. Якщо ж говорити про мовний світ письменника, то в цьому аспекті його твори вивчалися замало. Серед дослідників його творчості можна виділити Є.Г. Адельгейма, Б. Л. Корсунську, Б. В. Якубського, Т. В. Скорбач.

Мета нашого дослідження - простежити мовні засоби вираження простору міста у творчості М. Семенка.

Свої завдання вбачаємо в аналізі особливостей мовних та стилістичних засобів, які використовував поет для змалювання міста, його суті, образу, проблем, місця людини в ньому у своїх поетичних творах різних збірок.

У поезії М. Семенка, особливо в ранніх його творах, найбільш поширеним $є$ ідилічний простір села, який виражається традиційними мовними засобами, у пізніших творах цей тип художнього простору трансформується в простір реалістичний, позначений новими мовними засобами. Головним героєм поезії Семенка стає місто. Починаючи з перших збірок, воно поступово майже повністю охоплює його твори. Сучасник поета i критик В. Коряк про загальний характер творчості та новаторство поета говорив так: «Це перший український цілком міський поет і цілком відданий місту» [4, с. 40]. Водночас він - «кульмінаційна точка культу урбанізму в українській поезії. Далі після нього нікуди йти або доведеться повторюватися...» [4, с. 41]. Хоч, звичайно, сучасні критики досить слушно можуть не погодитися з цією думкою. Головним є те, що місто своїм гамором і шумом збуджувало уяву поета стократ більше, ніж оспівані в українській ліриці ніжні сільські краєвиди. Урбаністична тема, на думку Л. Коломієць, разом 3 темою кохання сплітаються в Семенка в оригінальну ритмічну конструкцію з гострих, ніби металічних, кутів, різких звуків, змережану пульсуючими нитками асоціацій [2, с. 9].

Місто в поезії М. Семенка - це і середовище ліричного героя, i середовище, з яким пов'язані художні переживання поета. Є. Адельгейм справедливо відзначав, що «місто - центр Семенкової лірики. Крізь побут міста він побачив і Людину, і Революцію, і Майбутнє. 3 містом виявилися пов'язані й ті питання оновлення поезіі, болісному вираженню яких письменник віддав майже все життя» [1, с. 398].

Перші поезії, що були присвячені місту, у яких найперше читач стикається $з$ цим образом, з'являються в 1914 році, коли поету виповнилося 22 роки. Про нову проблему і тему в його поетичній творчості свідчать самі назви поезій - «Улиця», «В кав’ярні», «Місто», «Ресторан» тощо. «Ці слова ввійшли в мовний світ поета настільки ж міцно, як відповідні явища його картини світу» [3]. Як і більшість футуристів, М. Семенко приймає ту дійсність, яку створює XX століття - динамічну, активну, спрямовану в майбутнє. Таку дійсність, де переважатимуть машини, літаки, де новим богом стане швидкість, де феномен «міста» олюднюється і саме місто немов би живе своїм власним, незалежним від людини, життям. У його поезіях 
місто і його найвиразніші ознаки починають міфологізуватися та виступати об'єктами для поклоніння.

Слово місто поет найчастіше вживає в його прямому значенні: Над містом туман [6, с. 58]; Люблю я міста безтемні звуки [6, с. 63]; Місто корчилось в жаданні бетонних поем [6, с. 74].

Місто має узагальнене значення - значення символу нової епохи, нового середовища, нового буття. I разом з тим місто для поета конкретне, що він виражає через назви явищ, подій, дій, які відбуваються в місті.

Аероплани над містом в небі

Розкидають палкі відозви [6, с. 94];

Я жуу коли вечір своє діло зробить

Коли рекламно охопить місто профанація

Коли засвітяться вогні $і$ згасне небо

I замигтить в очах святкова ілюмінація [6, с. 69].

Досить рідко поет дає місту або його частинам власні назви:

i питає поет розгублено:

аяк же «убий його»

і як же владивосток

ая жже париж $і$ лондон

чікаго і нью-йорк? [6, с. 118];

Хочу додому я,хочу в Київ... [6, с. 26];

Вабив Хрещатик розмальованими кралями [6, с. 75].

Ці й подібні власні назви уточнюють зміст образу і слова місто в поетичній картині світу письменника. Тому, гадаємо, можна говорити про два значення міста в поета: одне значення - це загальне значення-символ Miсто 3 його найхарактернішими загальними ознаками, а друге - це конкретне значення «місто Київ» чи «місто Мельбурн». Перше значення грунтується на поняттєвій основі лексичного значення, а в другому - на перше місце висувається його денотативний, предметний компонент.

М. Семенко вживає різноманітні слова на позначення геометричного членування міського простору: алея, (в)улиця, бульвар, парк, сад. Вулиці, сад поет описує у порівнянні 3 людиною і стосовно скупчення людей, (натовп, юрба, шум: сади гамірливо-бензинні [6, с. 53], вулиця сліпуча глумлива і німа [6, с. 67], роздратована вулиця [6, с. 81], самотна вулиця [6, с. 82], порожні вулиці [6, с. 108].

Символом самотності і кохання для поета є парк, адже саме там вони зустрічалися в останне з коханою:

Одягся парк у зодяг пишний,

У зодяг білий, сніговий,

І став він зимний, незатишний -

Чому, чому він став чуюний? [6, с. 44];

Зеленіє, зеленіє зосередковано

Самотній парк [6, с. 56]. 
Змальовуючи алеї, Семенко зробив акцент на атмосфері таємничості та інтимності: алеї півтемні [6, с. 25].

Рідше використовує поет такі слова як майдан і плащ::

На плацу трибуна,

Bci, всі до изентру! [6, с. 41];

На майданах натхненні гіпси [6, с. 84].

Слова майдан і плац у М. Семенка виступають як синоніми без відчутної відмінності у значенні, й автор заміщує їх одне одним у тексті 3 метою уникнення небажаних повторів.

Слово місто в поезіях Семенка має переважно позитивний оцінний компонент. Про це свідчить характер метафоричних значень слів, якими користується поет при змалюванні міського простору. Місто переважно святкове, радісне: трамваї веселі [6, с. 53], улиця сліпить [6, с. 68], вабив Хрещатик розмальованими кралями [6, с. 75], на вулицях незрівнянне свято [6, с. 93], на вулицях безмежний кортеж [6, с. 93], співом хитнеться місто [6, с. 93].

Місто в поета рухливе і живе. Слово місто в поезіях М. Семенка подається як назва живої істоти, воно персоніфікується через сполучення 3 дієсловами, які виражають дії, характерні для живих істот: Місто корчилось в жаданні бетонних поем [6, с. 74]; Місто затремтіло, заворушилось від бетонних мук [6, с. 88]; Заторохтіло місто залізними колесами [6, с. 88]; Співом хитнеться місто - відгуком мідяних труб [6, с. 93].

Невід'ємним елементом образу міста для М. Семенка є транспорт, який є образом втілення міського руху. Це знаходить вираження в частому вживанні слів на позначення транспортних засобів: автомобіль, експрес, підземка, трамвай.

Слово трамвай сполучається 3 епітетами блискучий, веселий, що виражає враження від нового дзвінкого яскравого транспортного засобу. Поет використовує з назвами транспорту різноманітні дієслова руху, що підкреслюють чи то витонченість, чи то стрімкість та швидкість засобу пересування: Пройшло 5 веселих трамваїв [6, с. 53]; Трамваї просковзують перемінними вогнями [6, с. 70]; I раптово знявся шум $i$ налетіли автомобілі [6, с. 82].

Так само як і наземний транспорт захоплює Семенка i повітряний, тому поет оспівує цей новий здобуток людства, який став частиною міського способу життя, а отже, і міського простору. У його поезії часто вживається не тільки слово аероплан, а й авіатор, аероліт: Аероплани над містом в небі... [6, с. 37]; Мертвопетлюе авіатор в хмарах [6, с. 40]; Можливо, щзо прибув на аероліті I кинув довкола зневажливий зір [6, с. 69].

Отже, можна зробити висновок, що в поезії Михайля Семенка місто різнопланове, проте має загальну позитивну конотацію. За допомогою дієслівних метафор у читачів створюється в уяві динамічна та рухлива міська атмосфера. Для Семенка місто - простір освітлений, сповнений 
блиску, що зумовлюється емоційним сприйманням поетом міста як середовища чогось радісного та небуденного. Широке використання назв транспорту та індустріальних реалій того часу дає змогу чітко простежити опозицію реалістичного, динамічного простору міста й статичного, ідилічного простору села. Метою нашого подальшого дослідження планується аналіз мовних засобів вираження міського простору в поезії В. Поліщука.

\section{Література}

1. Адельгейм Є. Михайль Семенко / Є. Адельгейм // Михайло Семенко. Поезії. - К. : Радянський письменник. $-311 \mathrm{c}$.

2. Коломієць Л. В. Переднє слово / Л. В. Коломієць // Семенко М. В. П'єро кохає : Вибрані поезії. К.: Укр. письменник, 1993. - 126 с.

3. Корсунська Б. Л. Михайль Семенко : Аналіз поетичної творчості / Б. Л. Корсунська // Радянське літературознавство. - 1968. - № 6. - С. 19-33.

4. Коряк В. Місто в українській поезії / В. Коряк // Шляхи мистецтва. - Х., 1921. - № 1. - С. 40 - 47.

5. Павличко С. Дискурс модернізму в українській літературі / С. Павличко. - К. : Либідь, 1999. - 448 с.

6. Семенко М. В. П'єро кохає : Вибрані поезії / М. В. Семенко. - К.: Укр. письменник, 1993. - 126 с.

7. Шерех Ю. Людина і люди (Місто В. Підмогильного) / Ю. Шерех. - Харків : Фоліо, 1998. - Т. 1. C. 81-91.

Стаття надійшла до редакції 7.11.2011 р. 